\title{
CAREX MARITIMA Gunn., AN ADVENTIVE SEDGE AT THE PAS, MANITOBA
}

\author{
by WILLIAM J. CODY* and WALTER KRIVDA**
}

Carex maritima is an arctic circumolar species which characteristically ccurs along sandy seashores. Thus, in North America it is found adjacent to he coasts of the arctic islands, along he arctic coast, the shores of Hudson nd James Bays and south along the abrador coast to Northern Newoundland where it is found on turfy imestone barrens.

Inland populations are quite rare nd scattered and usually in sandy ituations. On this continent these tations are only in the west: in the Brooks Mountain Range in Alaska, in he Ogilvie Mountains of Yukon and laska, at Lake Athabaska in Saskathewan, in the Banff region of outhern Alberta, near Edmonton, Alberta, and in the mountains of Colorado. Some of these inland collecions, as well as the one from York actory mentioned below, have been eferred to $C$. maritima var. incurviforhis (Mack.) Boivin (C. incurviformis Mack.) by Bernard Boivin (personal ommunication). A map depicting the ircumpolar range of the species is iven by Hultén'.

In Manitoba the only localities eported by Scoggan are from coastal ituations at York Factory and Chur-

Biosystematics Research Institute,

entral Experimental Farm,

ttawa, Ontario, KIA 0C6

*P.O. Box 864,

he Pas, Manitoba. chill\%. Indeed, it has been collected many times at the latter locality where it is sometimes quite robust in stature.

A new site has just been discovered at The Pas, Manitoba, about 400 miles SW of Churchill, near the Saskatchewan border. Here Carex maritima would appear to be an adventive, presumably carried in by the railroad. A single clone about one foot in diameter was found almost hidden in gravel; only the fruiting heads and upper parts of the leaves were protruding, and these were not observed until after rain. Data are as follows: Manitoba: The Pas, along railway in gravel, $W$. Krivda s.n., 8 June, 1973 (DAO and personal herbarium of W. Krivda).

Carex maritima often forms extensive mats, with acending tufts of leaves arising from deeply buried cord-like rhizomes; the generally arching culms which barely overtop the leaves may be low-growing or ascend to over 20 $\mathrm{cm}$ in height; the fruiting head consists of several tightly packed spikes of which the terminal one is inconspicuously staminate at the tip; the ovate and bluntish pistillate scales are brown with broad thin pale margins, and are exceeded by the divergent membranaceous subinflated perigynia. The var. incurviformis, which is doubtfully distinct, is reputed to have less inflated and somewhat nerved perigynia, and the scales lanceolate- 
ovate and only narrowly hyalinemargined.

Figure 1 depicts the plants collected at The Pas.
'HULTÉN, E. 1968. Flora of Alaska and Neigh loring Territories. Stanford University Pres Stanford, Calif. $1008 \mathrm{pp}$.

-SCOGGAN, H. J. 1957. Flora of Manitobe National Museum of Canada Bulletin 140: I 619.

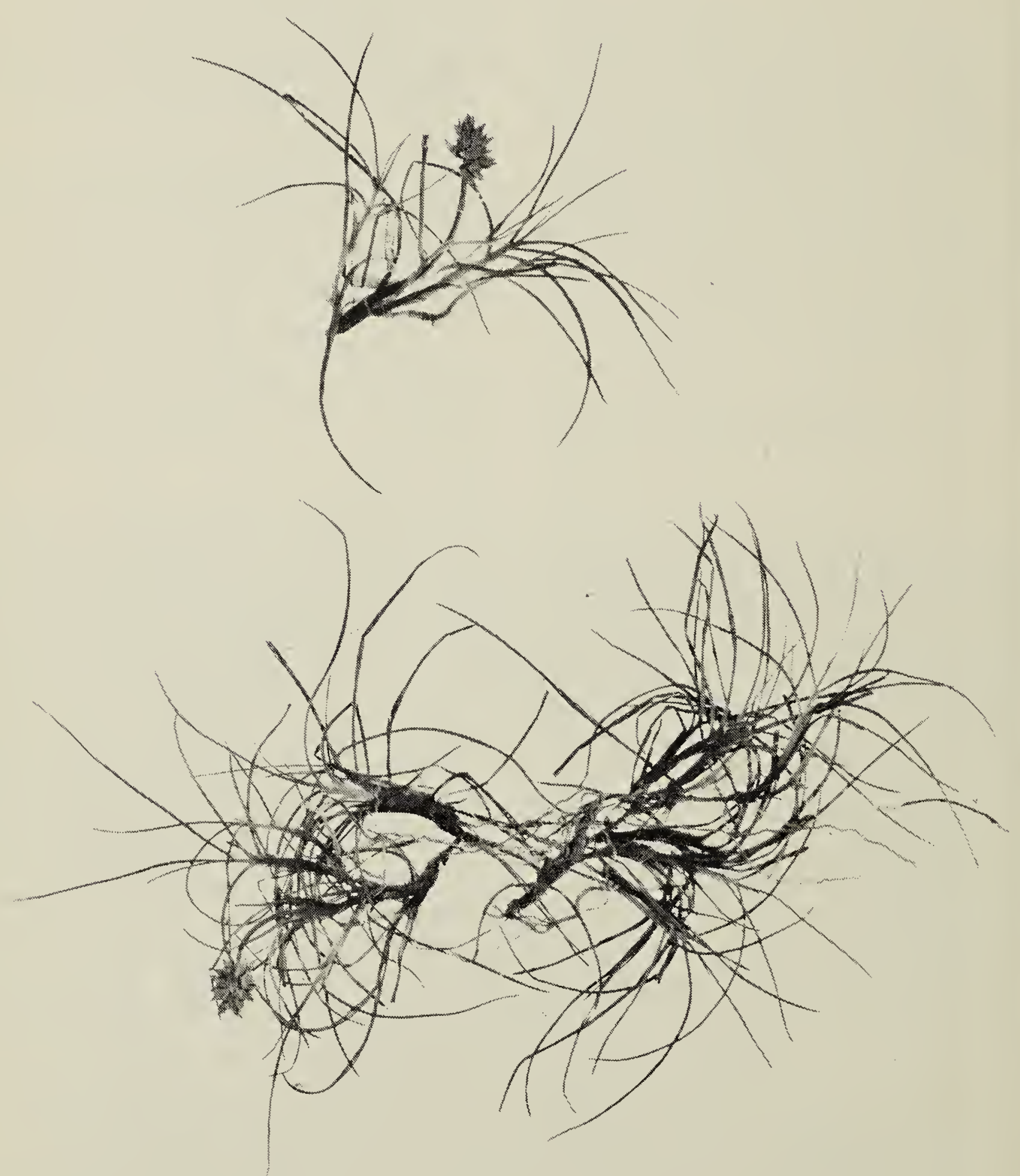

Figure 1. Carex maritima collected by W. Krivda at The Pas, Manitoba. 